\title{
THE DIURNAL ORDER OF THE IMAGE IN DRACULA, BY BRAM STOKER
}

\author{
O REGIME DIURNO DA IMAGEM EM DRÁCULA, DE BRAM STOKER
}

\author{
Claudio Vescia Zanini ${ }^{1}$
}

\begin{abstract}
In reality, the acceptance of the shadow-side of human nature verges on the impossible. Consider for a moment what it means to grant the right of existence to what is unreasonable, senseless, and evil! Yet it is just this that the modern man insists upon. He wants to live with every side of himself - to know what he is. That is why he casts history aside. He wants to break with tradition so that he can experiment with his life and determine what value and meaning things have in themselves, apart from traditional presuppositions.
\end{abstract}

Carl Gustav Jung. Psychology and Religion: West and East

\begin{abstract}
The article proposes a reading of Bram Stoker's Dracula analyzing the imagery in the novel in accordance with the Diurnal Order of the Image (DURAND, 1999), a perspective that encompasses images within three antithetical dichotomies: the theriomorphic and diceretic images (respectively related to an animal archetypology and to the devices and weapons of the hero), the nyctomorphic and spectacular images (related to darkness and light) and catamorphic and ascensional images, which are connected to falling and rising. The conclusion highlights the universality in the imagery Stoker employs in his work, which might explain Dracula's timelessness and power.
\end{abstract}

KEYWORDS: Dracula; Victorian literature; diurnal order of the image; vampire fiction.

RESUMO: O artigo propõe uma leitura de Drácula, de Bram Stoker analisando as imagens no romance de acordo com o Regime Diurno da Imagem (DURAND, 1999), uma perspectiva que engloba o imaginário com base em três dicotomias antitéticas: as imagens teriomórficas $e$ diairéticas (respectivamente relacionadas a uma arquetipologia animal $e$ às armas $e$ recursos do herói), as imagens nictomórficas e espetaculares (relacionadas à escuridão e à luz) e as imagens catamórficas e ascensionais, ligadas à queda e à ascensão. A conclusão ressalta a universalidade na imagética que Stoker emprega em seu trabalho, o que pode explicar a atemporalidade e o poder de Drácula.

PALAVRAS-CHAVE: Drácula; literatura vitoriana; regime diurno da imagem; fícção de vampiro.

\section{INTRODUCTION}

\footnotetext{
${ }^{1}$ Doutor em Estudos de Literatura pela UFRGS e professor dos programas de graduação e ós-graduação em Letras da Universidade Federal do Rio Grande do Sul.
} 
Dracula was published in 1897, a few years before the turn of the century and amid the commemoration of Queen Victoria's Diamond Jubilee. Although Bram Stoker's novel had predecessors such as John Polidori's The Vampyre (1819) and Sheridan Le Fanu's Carmilla (1872), Dracula's status as the most important piece of vampire fiction is unquestionable and confirmed by the amount of adaptations and appropriations in the form of onscreen series, role-playing games, comic books, and other cultural products.

If on the one hand general audiences and the media industry have welcomed the novel and profited from it, on the other hand academia has historically treated Dracula with contempt. When Oxford University Press announced that the novel had been chosen to be the one-hundredth title in its World Classic Series, they added in a clever albeit derogatory fashion that many of the other authors in their series, such as "Dickens, James, Tolstoy, and the like, would "no doubt turn over in their graves"" (BYRON, 1999, p. 12). In the introduction for this very special edition, A. N. Wilson apologetically observes that no one "in their right mind would think of Stoker as 'a great writer' or Dracula as 'a great work of literature"” (in STOKER, 1983, p. xiv). Indeed, it seems that

one of the world's best-known books was written by one of its least-known authors. As an object of serious critical study the novel has been, quite until recently, almost totally ignored. (...) As one critic has commented: 'Only a few years ago, to write about Dracula meant being taken for an eccentric loafer, and one's main worry was to prove that one's work was legitimate. (LEATHERDALE, 1986, p. 11)

Despite all controversy, Dracula remains powerful and timeless. This article intends to contribute towards a fuller understanding of such timelessness through an analysis of the novel's imagery, in accordance with some of Gilbert Durand's postulates in his 1960 treatise The Anthropological Structures of the Imaginary, which proposes a pedagogy of the imaginary through a bi-partite separation of images into the Diurnal and the Nocturnal orders. While the former is defined as the Order of antithesis, which studies the symbol under the perspective of polarized values, ideas and images expressed in dichotomies such as "being and not-being" or " "pure' and 'shadow" (DURAND, 1999, p. 66), the latter "is constantly characterized by conversion and euphemism" (DURAND, 1999, p. 191). Thus, what the Diurnal Order sees in terms of Manichaean dichotomies will be reconsidered and re-evaluated in the Nocturnal Order:

The Diurnal Order is concerned with the postural dominant, the technology of arms, the sociology of the magus-warrior-sovereign, and the rituals of elevation and purification, whereas the Nocturnal Order is subdivided into cyclical and digestive 
dominants, the cyclical dominants subsuming the techniques of the container and habitat, alimentary and digestive values, matriarchal and nurturing sociology; and the digestive dominant grouping together the techniques of the cycle, the agricultural calendar, the fabrication of textiles, natural or artificial symbols of return and myths and astrobiological dramas. (DURAND, 1999, p. 58)

Our focus is on the Diurnal Order, which Durand organizes into three antithetical dichotomies that serve as titles for the sections that present the analysis throughout the article, namely the theriomorphic and diceretic images (imagery related to an animal archetypology and to the devices and weapons of the hero, respectively), the nyctomorphic and spectacular images (related to darkness and light, respectively), and the catamorphic and ascensional images, respectively related to fall and rise.

Dracula's imagery recurs in the novel's abundant adaptations and appropriations, whose main feature is the presence of images and tropes traceable back to Stoker's work. A search on the Internet Movie Database using the term "dracula" yields 359 results, and it includes animations for children, comedies, pornography and documentaries. The list also comprises classics such as Friedrich Murnau's 1922 Nosferatu - a landmark in German Expressionism and one of the most notorious cases of plagiarism in the history of cinema and the 1931 Universal Studios rendition of the novel, which eternalized Bela Lugosi as the epitome of the vampire. A version spoken in Spanish was shot concomitantly to Lugosi's, starring Carlos Villarías as the Count, and although the Spanish Dracula did not become as successful as his Hungarian counterpart, the concern for a vampire movie tailored for a nonAnglophone market attested the impact of the vampire in people's collective unconscious, somehow initiating a democratization movement furthered in subsequent decades with the onscreen presence of black, gay, Latino and Asian vampires, for instance.

While the 1950s-1970s Hammer cycle featuring Christopher Lee and Peter Cushing consolidated a wholesome Dracula mythology, later movies made clear that eventually the movie industry had understood vampires were an artistic and financial investment worth making. The 1979 movie Dracula features Laurence Olivier, a Shakespearean Academy Award-winning actor, while the 1992 blockbuster directed by Francis Ford Coppola not only gathered a stellar cast, but it also garnered four Oscar nominations and three wins of its own. Eventually came appropriations that dragged the Count out of the fin-du-siècle Victorian England, such as Dracula A.D. 1972, Dracula 2000 and Dracula 3000, as well as franchises that explore different possibilities, such as the intricate familial, vampiric and homoerotic bonds in Anne Rice's Vampire Chronicles, or the moral dilemmas in Stephenie Meyer's Twilight, in which the vampire-prey dynamic is twisted due to the vampire's love for a young 
woman and his second thoughts about converting her. Onscreen vampire series have also become a genre in their own, as True Blood, Buffy the Vampire Slayer and The Vampire Diaries certify. Despite the diverse media, contexts of reception and diegetic spaces in these vampire stories, Dracula is the departure point for all of them, be it through reverence, direct or indirect reference, parody or perversion of tropes.

\section{THE VICTORIAN TURMOIL}

Durand's dichotomic theoretical framework is coherent with the overall late Victorian context, a time which "reflected in a peculiarly vivid and urgent way the social anxieties of their time" (CALDER, 1976, p. 9), and whose literature "exposes and explores the desires, anxieties and fears that both society and the individual (...) attain to suppress" (BYRON, 1999, p. 2) while expressing "both social and psychological dilemmas of the nineteenth century" (BYRON, 1999, p. 13). It is emblematic that a little more than a decade set apart the publication of powerful fictional works that exploit social anxieties through dichotomic metaphors. Such are the cases of Robert Louis Stevenson's The Strange Case of Dr. Jekyll and Mr. Hyde (1886) and its two protagonists who share the same body despite their different personalities, and Oscar Wilde's The Picture of Dorian Gray (1891), whose main plot lies in dichotomies such as youth/old age, good/evil, and appropriateness/desire. Both novellas capitalize on human quandaries and typical Victorian issues in a quite didactic way: while Stevenson's story may be read as an allegory of people's uneasiness towards scientific advancements (Darwin's polemic postulates in The Origin of Species had been published less than forty years before), Wilde updates the Faustian myth through a plot that challenges the place and validity of self-satisfaction, thus approaching an important issue for the novella's original intended audience and anticipating points Sigmund Freud will begin to explore in the theory of psychoanalysis a few years later.

The dichotomies Wilde and Stevenson present in their works corroborate the idea that the Victorians believed in institutions such as "patriotism, democracy, individualism, organized religion, philanthropy, sexual morality, the family, capitalism and progress (...) and, at the core, was the same tiny abscess - the nagging guilt as to the inherent contradiction between the morality and the system" (LANDOW, 2001). Dracula approaches these issues through an intricate web of elements that includes the mix of characters from diverse social backgrounds (Jonathan Harker and Mina Murray belong to the working class, Lucy Westenra's family is wealthy, and Arthur Holmwood is a nobleman) and nationalities 
(Abraham Van Helsing is Dutch, Quincey Morris is an American gentleman, and Dracula is not only from exotic Transylvania, but also a metaphor for the foreign/Eastern threat). In addition, the very structure of the novel suggests a dynamism that had recently become the paradigm for communication and the dissemination of information, as the inventions of the telegraph (1832), the British “one-penny" postal system (1840), and the telephone (1876) demonstrate. The multiplicity of voices and media present in Dracula's narrative scheme becomes a tool for the employment of a journalistic discourse that embeds this fantastic tale in an authority that is journalistic in nature (RICHARDS, 2009, p. 441), thus anticipating a tendency that has been paramount in the twenty-first century horror fiction - the story "based on real events" or filmed to look as realistic as possible, such as in false documentaries and found footage films.

Spiritual issues abound in the novel, above all due to the arguably sinful nature of the characters' contact with Dracula, which leads them to break religious and sexual rules alike. The two female protagonists are exemplary in that sense: Lucy's inconformity with the relationship rules for women becomes evident in her defense of polygamy, when in a letter to Mina she wonders “Why can't they let a girl marry three men, or as many as want her, and save all this trouble?" (STOKER, 1994, p. 76). She is punished by undergoing vampirization, a process that entails dying as a human being and subsequently becoming a tainted creature whose salvation depends on more profanation, since her walking corpse needs to be desecrated for the sake of purification. Conversely, Mina's transformation process is interrupted, and she is saved before becoming a vampire, but upon being touched on the forehead by a Holy Wafer she is burned and scared, to which she cries, "Unclean! Unclean! Even the Almighty shuns my polluted flesh! I must bear this mark of shame upon my forehead until the Judgment Day" (STOKER, 1994, p. 353). The characters' perception of Dracula as being impure adheres to Noël Carroll's correlation of impurity with the "transgression or violation of schemes of cultural categorization" (CARROLL, 1990, p. 31), in the sense that Dracula is neither alive nor dead. His status as an undead and his shapeshifting abilities (he turns into a bat, a dog, fog and mist) make him "categorically interstitial, categorically contradictory, incomplete or formless" (CARROLL, 1990, p. 32) in other terms, a monster that embodies some dichotomies that Durand poses as crucial for the Diurnal Order of the Image: "being and non-being [...] absence and presence [...] order and disorder" (DURAND, 1999, p. 66). The interplay of absence and presence is core in the novel's plot, given that Dracula is introduced in the first four chapters, when Jonathan goes to Transylvania and becomes a prisoner in the castle, and after this point the reader is barely 
given any access to Dracula's human form until the chase in the final chapters. Despite this absence, the vampire's presence is felt throughout the story, given that Dracula is responsible for Lucy's and Mina's mysterious loss of blood, Lucy's death, Renfield's madness, the slaughter in the ship and the death of Mr. Swales, for instance.

\section{THERIOMORPHIC AND DIARETIC IMAGES}

Dracula's materialization in the form of animals allows us to interpret his actions from the perspective of the theriomorphic symbols, which pertain to the symbology, universality and ubiquity of animal archetypology. Durand points out that when exposed to cards from the Rorschach test, most patients identified "aggressive animals reflecting powerful feelings of bestiality and aggression" (DURAND, 1999, p. 69). Dracula's cruel and predatory behavior throughout the novel is hinted at in Jonathan's first description of the Count, which resorts to intense animalization:

His face was a strong, a very strong, aquiline, with high bridge of the thin nose and peculiarly arched nostrils, with lofty domed forehead, and hair growing scantly round the temples but profusely elsewhere. His eyebrows very massive, almost meeting over the nose, and with bushy hair that seemed to curl in its own profusion. The mouth, so far as I could see it under the heavy moustache, was fixed and rather cruel-looking, with peculiarly sharp white teeth. These protruded over the lips, whose remarkable ruddiness showed astonishing vitality in a man of his years. For the rest, his ears were pale, and at the tops extremely pointed. The chin was broad and strong, and the cheeks firm though thin. The general effect was one of extraordinary pallor. (STOKER, 1999, p. 28, emphases added)

Durand's association of the animal with movement and agitation is perceivable in the novel upon the realization that the vampire's transformation in animals serve him the clear purposes of locomotion and access: Dracula becomes a dog in order to escape from the ship without raising suspicions, and he becomes a bat so as to have access to Lucy's and Mina's rooms, each in their due time. The theriomorphic symbols valorize sudden movement negatively, as they pertain to "schema of the flight from Fate" (DURAND, 1999, p. 72). Therefore, the movement is negative because it distances one from one's destiny. Dracula hides, assumes different forms to reach different places, and runs away in the final section of the novel, all in order to try to escape the destiny he is entitled to according to Victorian values: being the epitome of evil and sin, Dracula must be exterminated in the final chapter, even if it seems inconsistent with the power he displays throughout the story. 
The natural course of action in any analysis on animal imagery in Dracula is to focus on the bat. However, that posits a challenge when the framework in question is Durand's Diurnal Order, given that bats and other nocturnal birds are dismissed based on the argument that they are "simple products of darkness" (DURAND, 1999, p. 127). A solution for that problem is offered by the novel itself: since Dracula's animal manifestations are the bat and the dog, Durand's comments on canine images will encompass the bat whenever possible. Durand sustains that "for the Western imagination, the wolf is the savage animal par excellence" (1999, p. 83), and although Dracula euphemizes the wolf into a dog when he flees the ship, the concept of dental sadism Durand associates to canine images are pertinent for the understanding of both animal forms of the vampire. The teeth, a feature that has remained in most vampires, brings us to the "archetype of the sharp-toothed jaw" (DURAND, 1999, p. 77) that emulates a threatening animal mouth "equipped with sharp teeth, ready to crush and bite" (DURAND, 1999, p. 82). All the hideous fantasies are thus concentrated in the animal jaw: “agitation, aggressive mastication, sinister grunting and roaring" (DURAND, 1999, p. 83). Therein lies the main intersection between the wolf/dog and the bat in Dracula, for although Durand sustains that the wolf is dentally sadistic, it is the bat that preys and feeds on human blood.

The horse is also symbolically important in the novel, insofar as "in every case [related to the hippomorphic character of animal symbology] we have the general schema of animation together with anguish in the face of change, the voyage of no return and death" (DURAND, 1999, p. 74). This idea reinforces a quintessential archetypal image related to the horse, that of "the mysterious child of darkness and carrier of death" (CHEVALIER, p. 516), such as the ones pulling the carriage leading Jonathan to Castle Dracula in the first chapter. Jonathan's association of negative sensations to the dust the horses produce as they move corroborates the notion of horses and 'carriers of death': “As I looked back I saw the steam from the horses of the coach by the light of the lamps, and projected against it the figures of my late companions crossing themselves. (...) As they sank into the darkness I felt a strange chill, and a lonely feeling come over me" (STOKER, 1994, p. 11). This negative symbolic impact is furthered by the understanding that Dracula, who happens to be the carriage driver in disguise, uses his supernatural powers to control the horses: "At the first howl the horses began to strain and rear, but the driver spoke to them soothingly, and they quieted down, but shivered and sweated as though after a runaway from sudden fright" (STOKER, 1994, p. 12).

The contrastive category to the theriomorphic symbols is the one Durand calls diceretic. In opposition to the animalization and savage nature of the theriomorphic symbols 
Durand places the devices and weapons of the hero. Therefore, if the analysis of the theriomorphic symbols focuses mainly on the vampire, a search for the diæretic symbols will emphasize its persecutors, thus enhancing the Manichaean character of the Diurnal Order. The fighting hero is mostly symbolized through the Prince Charming archetype in fairy tales, the one who "provides protection against evil spells and renders them harmless, who discovers, delivers and awakes" (DURAND, 1999, p. 157). Such figure only exists in Dracula if the five persecutors - Jonathan Harker, John Seward, Abraham Van Helsing, Quincey Morris and Arthur Holmwood - are amalgamated. This group comes full cycle with the diæretic symbolism, whose nature is predominantly masculine: they gather their weapons and chase Dracula until the fulfillment of their mission. The archetypal image of the vampire hunter includes the stake, an example of the "sharp-edged or pointed weapons" (DURAND, 1999, p. 155) that constitute both the core in the diæretic symbolism and the main argument for the psychoanalytical readings of Dracula that emphasize the phallic (thus masculine) aspect of such weapon. The purification of Lucy's vampire version happens through the penetration of the stake through her heart, an act perpetrated by Arthur, her fiancé.

Another pointy and possibly sharp-edged weapon used in vampire combat is the crucifix. If "the weapon with which the hero is equipped is a symbol of both power and purity" (DURAND, 1999, p. 156), then Dracula's impurity becomes more blatant, for the crucifix implies sacrifice, nobility and faith. The noble character of the heroic quest justifies anything - even murder, which is what the five men and Mina ultimately perpetrate against Dracula. Heroes struggle against the "ruses of time and the snares of Evil" (DURAND, 1999, p. 162), which may lead to a shift in their symbolic intentions; in other terms, the mortal heroes are allowed to kill because their target is a vampire, a creature whose evil triggered such reaction; therefore, the violent action is not the heroes' fault, and is justified through the monster's darkness, one of the two opposite poles exploited by the second pair of contrasting images proposed by the Diurnal Order, covered in the following section.

\section{NYCTOMORPHIC AND SPECTACULAR IMAGES}

The nyctomorphic symbols pertain to images of darkness and the impact they may cause, such as "a character wearing black" (DURAND, 1999, p. 88). Durand reminds us that we "have all been sensitive to the nocturnal, blind, disturbing aspect of the unconscious side of the soul. The dark confidant and gloomy counselor, Mephistopheles, is the prototype of the many Doppelgänger 'clad in black' who resemble us 'like a brother'” (DURAND, 1999, p. 
92). Suggesting that this character wearing black from head to toe may be a Doppelgänger (“double goer", or "double walker" in German) recalls Freud's postulates in The Uncanny, a term he defines as something "long known to us, once very familiar" (FREUD, p. 1-2), and invariably concerned with the phenomenon of the 'double', the process of "doubling, dividing and interchanging of the self' (FREUD, p. 9). The vampire in Stoker's work is a product of fears and anxieties, as are all vampires. Dracula's aura of mystery, shapeshifting and physical absence for the better part of the plot leaves the reader 'in the dark', and such darkness entails blindness, another theme within the nyctomorphic symbology.

Human rationality and pragmatism rely on sight, among other aspects, to determine whether something is right or possible. Dracula's phantasmagoric presence/absence in association to his actions - without which there would be not plot at all - lead to "a weakness of intellect" (DURAND, 1999, p. 92), a sort of blindness itself. Dracula toys with what is real and feasible not only in Victorian times, but also in other contexts. The events in the plot force the European intellectuals and men of science, represented especially in the character of doctor John Seward, to question their sanity and beliefs. People returning from their graves to feed on the blood of the living, sudden changes of the weather or wild animals that obey to one single command are facts that force rational (wo)men and readers alike into a world of darkness, and consequent blindness.

Water is also paramount in nyctomorphic symbology. It is the mineral element that constitutes the universal archetype of the dragon, which allows yet another connection to Dracula through the word's etymology. One of historical inspirations for the fictional vampire, Vlad Tepes (1431-1476), was the son of a man also named Vlad, who eventually joined a Christian order called "the society of the Dragon". Tepes' father thus adopted the surname Dracul, which in ancient Romanian is the junction of the word "drac" ("dragon") and the particle "ul" ("the son of").

\footnotetext{
The statute which survives in a copy dated 1707 states that the Order also required its initiates to defend the Cross and to do battle against its enemies, principally the Turks. (...) It adopted as its symbol in 1408 the image of a circular dragon with its tail coiled around its neck. On its back, from the base of its neck to its tail, was the red cross of St George on the background of a silver field. With the expansion on the Order, other symbols were adopted, all variations on the theme of dragon and cross. (MILLER, 2000, p. 19)
}

When Vlad Tepes joined the order, he became known as "Dracula", with the particle "a" also meaning "the son of". Despite this historical connection, the imagery embedding the Count allows us to see him as a dragon of sorts, since "the imagination seems to construct the 
archetype of the Dragon (...) on the basis of fragmentary terrors, disgusts, fears, instinctive as well as experienced repulsions, and ultimately to set up the archetype as an awe-inspiring entity" (DURAND, 1999, p. 96). Durand also associates the archetype of the dragon to evil femininity: the biblical book of Revelations links the Dragon and the archetype of the Sinful Woman, or the Great Prostitute of the Apocalypse (DURAND, 1999, p. 95), an association Dracula parallels via Lucy's vampirization. She undergoes physical changes that ensure the negative valorization of the female vampire, "the woman of darkness, the evil water-spirit who (...) uses her bewitching femininity to assume the power hitherto attributed to predatory animals" (DURAND, 1999, p. 99). More than becoming a vampire, Lucy becomes a "vamp", a female archetype the Diurnal Order sees as the junction of cruelty and depravity to a delightful appearance. She is also "fate, the ghoul, the black soul of the world and of death" (DURAND, 1999, p. 102).

Opposed to the darkness of the nyctomorphic symbols are the spectacular symbols, which are related to visual light that eventually leads to metaphorical light. The strongest archetypal image of this category is the sun, which renders a difficulty in analyzing Dracula, for most of the action of the novel takes place at night. Durand traces a parallel between the sun and Jesus Christ, by pointing out that in medieval times Christ was compared to the sun, and called sol salutis, or sol invictus. Accordingly, this relationship is clear: the vampire is seen as an Anti-Christ in terms of values and morals, and at the same time it weakens when the sun is high. Contemporary media have exponentialized the effects of sunlight on the vampire for dramatic and visual purposes. However, Van Helsing never mentions death when he stresses that the vampire's power "ceases, as does that of all things, at the coming of the day" (STOKER, 1994, p. 287).

Spectacular symbols (and the ascensional ones as well, as will be seen in the next section) are both confirmed and perverted in Dracula. The universal archetype of the light is isomorphically connected to the physical ascension, and "it is luminous ascent that gives a positive value to the sun" (DURAND, 1999, p. 145). The novel suggests an inversion of that idea, given that the Count rises both concretely in its flying shape of a bat and metaphorically, insofar as he succeeds in his endeavors throughout most of the plot, to be killed only in the final chapter. Thus, the ascension imagery in the novel is predominantly associated to the night, and consequently to darkness. The spectacular success proposed in the Diurnal Order is only implied by the ending of the novel, since Dracula's demise indicates that his prosperity forged in darkness is not permanent. 
The notion of a "black sun" (DURAND, 1999, p. 145) twists the traditional association of the sun as illuminating and life-fostering by referring to evil and its devouring aspect. The imagery in Dracula sustains the paradox, for if on the one hand it still means life and hope for the human characters, it devours the vampire's strength and prevents him from performing. Another perversion within the spectacular symbology of the sun lies in its association with the East, and the idea "it is in the East that the Earthly Paradise is situated and it is there that the Psalmist situates the Ascension of Christ, and St Matthew the return of Christ" (DURAND, 1999, p. 145). In the novel, what comes from the East is a lethal threat with powers to change the world as the Victorians knew it.

\section{CATAMORPHIC AND ASCENSIONAL IMAGES}

The third and final antithetical pair in the Diurnal order comprises the catamorphic and ascensional symbols. The catamorphic symbology refers to the third main expression of human imagination reacting in anguish to time, provided by dynamic images of the fall. "The fall appears as the existential quintessence of the dynamics of darkness" (DURAND, 1999, p. 109), and the movement downwards is frequently associated to the symbols of fornication, jealousy, anger, idolatry and murder, elements that Dracula bears in its plot. One of the most famous biblical episodes, Adam and Eve's eviction from Paradise, is known as "The Fall of Man”, and just like Dracula, it features a dangerous animal form, the crossing of boundaries and the fascination with transgression.

\footnotetext{
Now the serpent was more crafty than any of the wild animals the Lord God had made. He said to the woman, 'Did God really say, 'You must not eat from any tree in the garden'?' The woman said to the serpent, "We may eat fruit from the trees in the garden, but God did say, 'You must not eat fruit from the tree that is in the middle of the garden, and you must not touch it, or you will die.' (Genesis: 3, 1-3)
}

The characters in Dracula that best exemplify the catamorphic imagery are Lucy and Renfield, for their involvement with the vampire/dragon/serpent leads to their fall. The sinful character of Lucy's connection to Dracula relates to fornication (it is part of the negative valorization of femininity discussed in the section about nyctomorphic symbology), whereas Renfield represents both idolatry - Dracula is his god - and refusal to God after Dracula promises him power. Lucy literally ends up under the ground when she is buried, in yet another symbolic display of the catamorphic character of her vampirization.

One of the explanations for the downward movement is human anguish in the face of time, pervaded with an ogre-like aggressiveness whose main characteristic is the traumatism 
of teething. Besides the obvious connection between teeth-related imagery and vampire, Dracula is in a way as a metaphor for time that "appears as a disturbing animate being and a terrifying devourer, (...) referring either to the irrevocably fleeting aspect, or to the insatiable negativity of destiny and death" (DURAND, 1999, p. 118). Count Dracula simultaneously perverts time and causes anguish, for a) it belongs in Medieval Transylvania and Victorian England; b) like time, Dracula is felt but not seen, and c) when given the chance to act, Dracula, once again like time, eventually fulfills the "negativity of destiny and death" (DURAND, 1999, p. 118).

The counterparts for the catamorphic symbols are the ascensional ones, which refer to the movement upwards, to the act of flying and to high places. The cross, which is used in Dracula as an instrument to repress the vampire, is held in Christian tradition as "the ladder of sinners" or the "divine ladder" (DURAND, 1999, p. 123). The positive valorization of the ascent is reinforced, as the cross is considered a way up to reach God and escape a terrible physical death. The dualisms inherent to the Diurnal Order are perceived in the ascensional symbols due to the contrast of "spiritual verticality to carnal flatness or to the fall" (DURAND, 1999, p. 123). In the attempt of reaching God the ones who manage to escape the vampire's dazzle avoid the fall, which is represented in the novel by vampirization and the pollution of the flesh. Mina encompasses both instances, for her flesh is marked when she is on the verge of becoming a vampire, but she avoids the fall by relying on her mental powers, among which faith is arguably included.

The ascensional movement is intrinsically linked to the wing, the exemplary means of ascension: "dreams of flying, while technically absurd, are accepted and given a privileged status in angelistic inspirations" (DURAND, 1999, p. 126). The imagery in Dracula does not substantiate this particular instance of the ascensional symbology, seeing that the only flying image of the novel is that of Dracula converted into a bat, whereas the ascensional movement focuses on God's angels, birds and butterflies. Bats and nocturnal birds form "a group quite distinct from other theriomorphic symbols" (DURAND, 1999, p. 127), and due to their dark nature, are excluded altogether from the ascensional symbols.

\section{FINAL REMARKS}

The analysis of the imagery in Dracula from the perspective offered by the three antithetical dichotomies in the Diurnal Order of the Image demonstrates that Manicheanism is a key factor in the organization of the diurnal pedagogy of image. Although this notion 
enables oversimplifications and superficial readings, it must be acknowledged as one of the most powerful resources in Bram Stoker's novel. It is, among so many things, a tale about the struggle between good and evil, and the fact that Manicheanism tends to transcend any cultural or political difference (indeed, it is the foundation for many social organizations) assures that reading Dracula will remain pertinent, and so will adapting it. Nonetheless, underneath the peel of Manicheanism, the analyses presented here enhance the complexity of Stoker's novel precisely in the figure of its protagonist: Dracula challenges time by growing younger and surviving centuries. He leads the women on his way to damnation, but not without giving them first the chance of experiencing an unknown sort of social and sexual liberty deriving from the breaking of unsatisfactory social conventions. The vampire is not dead, and yet, he is not alive. His contact with the unknown is as repelling as it is enticing, and it necessarily happens when fiction presents us an impure, interstitial, and attractive monster.

A symbol is "the best possible expression for an unconscious content whose nature can only be guessed, because it is still unknown" (JUNG, 1969, p. 6), something that "surmount[s] natural contradictions and bind[s] together irreconcilable elements, social partitions and segregated periods of history" (DURAND, 1999, p. 39). Thus, vampires have been for centuries expressions of diverse feelings, states of mind and moods. Count Dracula remains the most powerful among these symbols, not only because its context of creation was particularly important in the formation of modernity, but above all due to its universal imagery, which has conveyed meanings for millions of people over the past one hundred and twenty years. Due to its symbolic images and tropes, Bram Stoker's work will most likely remain fundamental, powerful and profoundly paradoxical.

\section{REFERENCES}

BYRON, Glennis (editor). Dracula: contemporary critical essays. New York: St. Martin's Press, 1999.

CALDER, Jenni. Women and marriage in Victorian fiction. London: Thames and Hudson, 1976.

CARROLL, Noël. The philosophy of horror, or paradoxes of the heart. London: Routledge, 1990.

CHEVALIER, Jean. A dictionary of symbols. (Translated by John Bucanan-Brown). London: Penguin, 1997.

DURAND, Gilbert. The anthropological structures of the imaginary. (Translated by Margaret Sankey and Judith Hatten). Brisbane: Boombana, 1999. 
FREUD, Sigmund. The uncanny. (Translated by Alix Strachey) Available at $<$ http://web.mit.edu/allanmc/www/freud1.pdf > Date of access: 29 Aug 2018.

JUNG, Carl Gustav. Psychology and religion: west and east. (Translated by R. F. C. Hull). New York: Princeton University Press, 1977. $2^{\text {nd }}$ ed.

. The archetypes and the collective unconscious (Translated by R. F. C. Hull). New York: Princeton University Press, 1969. $2^{\text {nd }}$ ed.

LANDOW, George. P. The reality of Victorianism. Available at < http://www.victorianweb.org/vn/victor7.html > Date of access: 29 Aug 2018.

LEATHERDALE, Clive. Dracula: the novel and the legend: a study of Bram Stoker's Gothic masterpiece. London: Aquarian Press, 1986.

MILLER, Elizabeth. Dracula. New York: Parkstone Press, 2000.

RICHARDS, Leah. Mass production and the spread of information in Dracula: "proofs of so wild a story" English Literature in Transition, 1880-1920. ELT Press. Volume 52, Number 4, pp. 440-457, 2009.

STOKER, Bram. Dracula. London: Penguin, 1994.

. Dracula. World Classic Series. London: Oxford, 1983.

THE HOLY BIBLE: New International Version. Zondervan. Grand Rapids, 1989.

Recebido em 30/08/2018. Aceito em 19/10/2018. 